\title{
Selective Extraction of Manganese using Moringa oleifera Seeds as Bioadsorbent
}

\author{
Sângela Nascimento do Carmo, José Alistor de Sousa Neto², Vanessa Nunes Alves ${ }^{2} \bigotimes$ (iD \\ Luciana Melo Coelho², Nívia Maria Melo Coelho'
}

${ }^{1}$ Instituto de Química, Universidade de Uberlândia. Av. João Naves de Ávila, 2121, 38400-902, Uberlândia, MG, Brazil ${ }^{2}$ Departamento de Química, Universidade de Goiás. Av. Dr. Lamartine Pinto de Avelar, 1120, Setor Universitário, 75704-020, Catalão, GO, Brazil

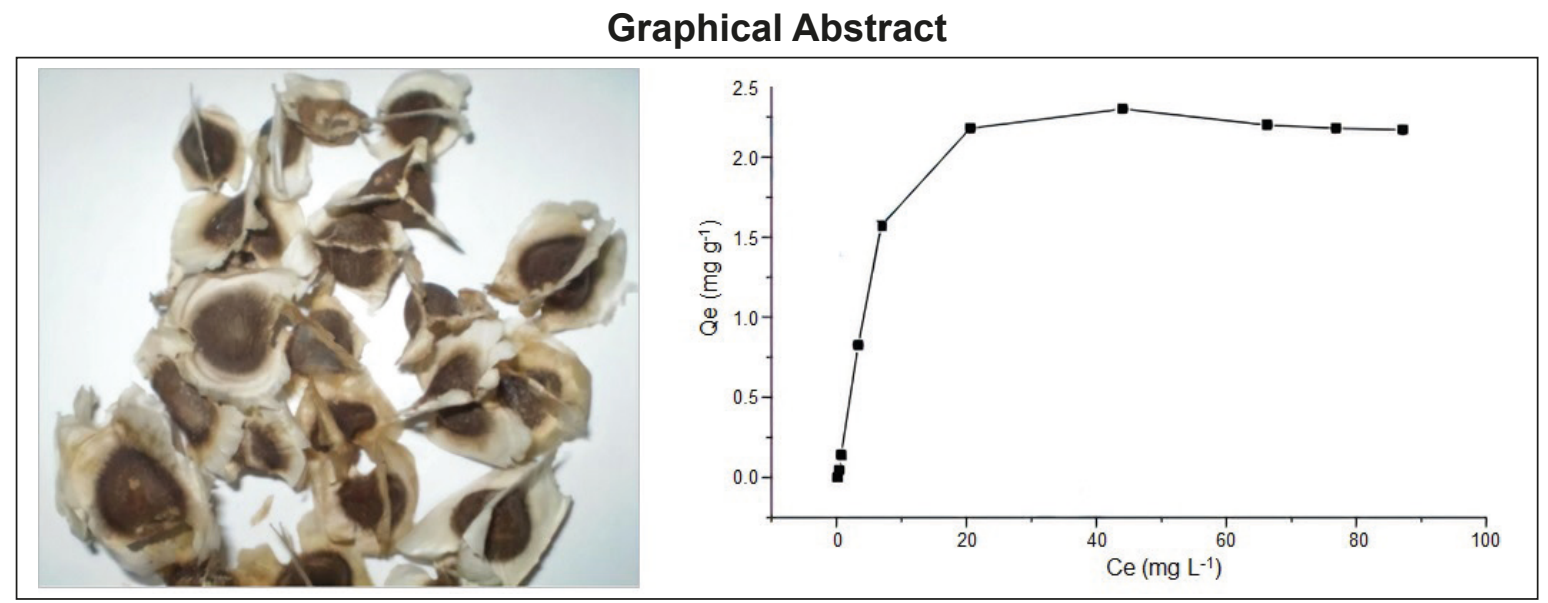

Moringa oleifera seeds used for selective extraction of manganese in aqueous samples. Around $60 \%$ of the $\mathrm{Mn}(\mathrm{II})$ was removed at an initial pH of 3.0. The maximum adsorption capacity for $\mathrm{Mn}(\mathrm{II})$ was $10.35 \mathrm{mg} \mathrm{g}^{-1}$.

The adsorption of manganese onto Moringa oleifera seeds was optimized as a function of $\mathrm{pH}$, adsorbent mass, particle size and contact time in aqueous solutions in batch tests. The results show that the optimized conditions for manganese adsorption were: $\mathrm{pH} 3.0$, particle size $\leq 180 \mu \mathrm{m}$, adsorbent mass $1.0 \mathrm{~g}$ and contact time $15 \mathrm{~min}$. Varying the $\mathrm{pH}$ allowed the separation of the manganese species, the seeds selectively retained $\mathrm{Mn}(\mathrm{II})$ while $\mathrm{Mn}(\mathrm{VII})$ remained free in solution. Around $60 \%$ of the $\mathrm{Mn}(\mathrm{II})$ was removed at an initial $\mathrm{pH}$ of 3.0 with a manganese concentration of $4 \mathrm{mg} \mathrm{L}^{-1}$. The adsorption process was evaluated through adsorption isotherms and kinetics studies. The maximum adsorption capacity for $\mathrm{Mn}(\mathrm{II})$ was $10.35 \mathrm{mg} \mathrm{g}^{-1}$. The isotherm followed the Langmuir model and the adsorption kinetics followed a pseudo-second-order kinetic model.

Keywords: manganese, selective extraction, Moringa oleifera.

\section{INTRODUCTION}

Manganese $(\mathrm{Mn})$ is the tenth element in order of abundance in the earth's crust and it is mainly used in metallurgical processes, approximately $90 \%$ being used in the manufacture of steel, and as a component in metallic alloys. Other uses of Mn include the manufacture of ceramics, dry cell batteries and pigments. These activities constitute the major anthropogenic sources of this metal to the aquatic environment [1].

Manganese is an essential micronutrient in the human diet. It activates many enzymes used in metabolic processes and is also required for protein and fat metabolism. Mn helps to maintain 
healthy nervous and immune systems and to regulate blood sugar levels [2-4]. However, high doses of manganese cause DNA mutations, neurological disorders (e.g., manganism), overflow of the liver, hallucinations, depression and excessive sleep [5,6]. Therefore, the study of trace elements is gaining importance, especially when these elements are present in the environment in different oxidation states [7]. There are 11 oxidation states of manganese, the most prevalent being $\mathrm{Mn}(\mathrm{II}), \mathrm{Mn}(\mathrm{IV})$ and $\mathrm{Mn}(\mathrm{VII})$, and their order of toxicity is $\mathrm{Mn}(\mathrm{II})>\mathrm{Mn}(\mathrm{VII})>\mathrm{Mn}(\mathrm{IV})$ [8]. In this context, it is essential to establish methods for the removal of this metal, especially $\mathrm{Mn}(\mathrm{II})$, which is the most toxic species in aqueous or solid effluents.

Precipitation as a hydroxide is one of the most commonly used techniques for metal removal, through its reaction with a base added to the effluent; however, this procedure is not appropriate for low concentrations.

The use of solid phase extraction (SPE) has been frequently proposed as a technique for metal removal and it is suitable for use in batch or flow experiments. The choice of the adsorption phase is dependent on the adsorption capacity associated with each species considered [9].

The use of natural adsorbents has been successfully employed in metal ion adsorption. The significant benefits of adsorption processes include effective and economical contaminant removal, recovery of the adsorbent metals from the adsorbent and its recycling, low sludge production, simple process procedures and high removal efficiencies. In this context, the Moringa oleifera seeds have been gaining attention. Moringa seeds have been most widely applied as a coagulant agent, but many studies have been performed in order to explore other potential applications of this material, especially in the removal of metals from aqueous systems. This material is of low cost and is easy to obtain, and it has good potential for application in procedures for the removal and selective extraction of metal ions [10].

The aim of this study was to describe the use of $M$. oleifera seeds for the extraction of $\mathrm{Mn}$ (II) from natural water samples, since the physiological and toxicological effects of manganese are dependent on its chemical form [11], the bivalent species being the most toxic.

\section{MATERIALS AND METHODS Adsorbent Preparation}

The Moringa oleifera seeds were obtained from trees which were cultivated in the city of Uberlândia (Minas Gerais, Brazil). The seeds were separated from the pods, crushed in a household blender (Black \& Decker, São Paulo, Brazil) and sieved at 500, 300 and $180 \mu \mathrm{m}$. They were then washed in deionized water and dried at ambient temperature. The functional groups present in the seeds were characterized using a Fourier transform infrared (FT-IR) spectrometer (Shimadzu, IR Prestige-21, Tokyo, Japan).

\section{Manganese Determination}

A Varian Model SpectrAA 220 (Victoria, Australia) flame atomic absorption spectrometer, with airacetylene flame, was used for the manganese determination. A manganese hollow cathode lamp was run under the conditions recommended by the manufacturer. The wavelength used was $279.5 \mathrm{~nm}$ and conventional values were applied for the slit width and burner height.

\section{Standard Solutions and Reagents}

All solutions were prepared with analytical grade reagents and high purity deionized water produced by a Milli-Q ${ }^{\circledR}$ system (Millipore, Bedford, MA, USA). The glassware and containers for the storage of the solutions were immersed in $10 \%(\mathrm{v} / \mathrm{v})$ nitric acid and rinsed with deionized water before use. The working solutions of $\mathrm{Mn}(\mathrm{II})$ were prepared through dilution of a $1000 \mathrm{mg} \mathrm{L}^{-1}$ stock solution (Carlo Erba, Val de Ruil, France) in deionized water. Since a stock solution of Mn(VII) was not available, the $1000 \mathrm{mg}$ $\mathrm{L}^{-1}$ solution of this species was prepared by dissolving $0.034 \mathrm{~g}$ of $\mathrm{KMnO}_{4}$ (Vetec, Rio de Janeiro) in 100 $\mathrm{mL}$ of deionized water. Solutions of $0.1 \mathrm{~mol} \mathrm{~L}^{-1} \mathrm{HNO}_{3}$ and $0.1 \mathrm{~mol} \mathrm{~L}^{-1} \mathrm{NaOH}$ were used to adjust the $\mathrm{pH}$. 


\section{Adsorption Studies}

The solution $\mathrm{pH}$ is a critical variable that directly affects the ion adsorption. Moringa oleifera seeds can adsorb cations or anions depending on the $\mathrm{pH}$ solution. The effect of the $\mathrm{pH}$ solution on the $\mathrm{Mn}$ (II) and $\mathrm{Mn}(\mathrm{VII})$ separation was investigated by varying the $\mathrm{pH}$ from 1 to 8 . In this procedure, $0.5 \mathrm{~g}$ of seeds were shaken for 40 minutes with $25 \mathrm{~mL}$ of a manganese solution containing one of the Mn species $\left(4.0 \mathrm{mg} \mathrm{L}^{-1}\right)$. The suspension was then filtered, and the supernatant was directly analyzed by flame atomic absorption spectrophotometry ( $F$ AAS). The amount of manganese retained in the biosorbent was calculated by the difference between the initial and final manganese concentrations in the solution.

The $\mathrm{pH} 3.0$ is the $\mathrm{pH}$ at which separation of the manganese species occurs and this value was used in order to obtain the optimum conditions for $\mathrm{Mn}(\mathrm{II})$ adsorption. The following variables were studied: particle size (180 to $500 \mu \mathrm{m}$ ), adsorbent mass ( 0.05 to $4.0 \mathrm{~g}$ ) and stirring time (5 to $120 \mathrm{~min}$ ).

\section{Studies on Interference from Ions in Mn(II) Adsorption}

The $\mathrm{Mn}(\mathrm{II})$ adsorption in the presence of $\mathrm{Na}^{+}, \mathrm{Ca}^{2+}, \mathrm{Mg}^{2+}$ and $\mathrm{Fe}^{3+}$, considered as concomitant ions, in various proportions, was evaluated. The experimental conditions were: $\mathrm{pH}$ 3.0, particle size $500 \mu \mathrm{m}$, adsorption mass $2 \mathrm{~g}$ and stirring time $15 \mathrm{~min}$.

\section{Isotherm Adsorption}

The experiments for the isotherm tests were carried out at a temperature range of 25 to $28{ }^{\circ} \mathrm{C}$ using $50.0 \mathrm{mg}$ of moringa seeds $(500 \mu \mathrm{m})$ and $50 \mathrm{~mL}$ of $\mathrm{Mn}(\mathrm{II})$ solution in a concentration of 0.2 to $100 \mathrm{mg}$ $\mathrm{L}^{-1}$. The $\mathrm{pH}$ of the mixture was adjusted to 3.0 and the stirring time was $60 \mathrm{~min}$. The mixture was filtered and the $\mathrm{Mn}(\mathrm{II})$ was quantified using flame atomic absorption spectrometry (FAAS).

\section{Kinetic Studies}

The kinetics of the $\mathrm{Mn}(\mathrm{II})$ adsorption onto moringa seeds in the batch tests was investigated. In this study, $0.05 \mathrm{~g}$ of moringa seeds were added to $50 \mathrm{~mL}$ of the solution containing manganese ions in the concentration of $4 \mathrm{mg} \mathrm{L}^{-1}$ in polyethylene jars. The mixtures were agitated at $180 \mathrm{rpm}$ for intervals between 5 and $120 \mathrm{~min}$. After agitation, the mixture was filtered and the manganese concentration determined by F AAS.

The adsorption capacity of the adsorbent $\mathrm{q}\left(\mathrm{mg} \mathrm{g}^{-1}\right)$ in relation to manganese ions was calculated by the Equation 1:

$$
q=\left[\left(C_{0}-C_{f}\right) / m\right]^{*} V_{S}
$$

where $\mathrm{C}_{\mathrm{O}}$ is the initial concentration in $\mathrm{mg} \mathrm{L}^{-1}, \mathrm{C}_{\mathrm{f}}$ is the final concentration in $\mathrm{mg} \mathrm{L}^{-1}, \mathrm{~m}(\mathrm{~g})$ is the adsorbent mass and $\mathrm{V}_{\mathrm{S}}(\mathrm{L})$ is the solution volume.

The kinetic parameters of the manganese adsorption process by moringa seeds were determined through linear regression of the graphs for pseudo-first-order, pseudo-second-order model and intraparticle diffusion using the respective equations given below $[12,13]$.

$$
\log _{10}\left(q_{e}-q\right)=\log _{10}\left(q_{e}-k\right)^{*} t
$$

where $\mathrm{q}_{\mathrm{e}}$ and $\mathrm{q}$ are the amounts adsorbed from the solution $\left(\mathrm{mg} \mathrm{g}^{-1}\right)$ at equilibrium and at time (t), respectively, and $\mathrm{k}$ is the adsorption rate constant $\left(\mathrm{min}^{-1}\right)$. The constant $\mathrm{k}$ is calculated from the slope of the line in the graph $\log \left(q_{e}-q\right) \times t$. This model considers that the sorption rate is dependent on the number of active sites available.

$$
\frac{t}{q}=\left(\frac{1}{k_{2}} x \frac{1}{q_{e}^{2}}\right)+\left(\frac{1}{q_{e}}\right) t
$$


where $\mathrm{k}_{2}$ is the pseudo-second-order constant $\left(\mathrm{g} \mathrm{mg}^{-1} \mathrm{~min}^{-1}\right), \mathrm{t}$ is the time $(\mathrm{min})$ and $\mathrm{q}_{\mathrm{e}}$ and $\mathrm{q}$ are the amounts of solute adsorbed $\left(\mathrm{mg} \mathrm{g}^{-1}\right)$ at equilibrium and at time $t$, respectively. From the plot of $t / q \times t$, the values of the constants $\mathrm{k}_{2}$ and $\mathrm{q}$ can be calculated. The $\mathrm{k}_{2}$ constant is used to calculate the adsorption rate " $\mathrm{h}$ " ( $\left.\mathrm{mg} \mathrm{g}^{-1} \mathrm{~min}^{-1}\right)$ for $\mathrm{t}_{0}$, as follows: $\mathrm{h}=\mathrm{k}_{2} \mathrm{q}_{\mathrm{e}}{ }^{2}$. For the intra-particle diffusion model this equation is:

$$
q_{t}=k_{\text {dif }} t^{1 / 2}+C
$$

where $q_{t}$ is the amount of adsorbed solute $\left(\mathrm{mg} \mathrm{g}^{-1}\right)$, $t$ is the agitation time (min) and $C\left(\mathrm{mg} \mathrm{g}^{-1}\right)$ is the constant related to the resistance to the diffusion. The $\mathrm{k}_{\text {dif }}\left(\mathrm{mg} \mathrm{g}^{-1} \mathrm{~min}^{-0.5}\right)$ can be obtained from the slope and the $C$ value from the intersection of the curve for $q_{t}$ versus $t^{0.5}$ [14].

According to this model, when the intraparticle diffusion is involved in the sorption process, the curve defined by this equation must be linear.

\section{Accuracy Tests}

To verify the selective adsorption of $\mathrm{Mn}(\mathrm{II})$, standard addition and recovery tests were carried out with samples containing $\mathrm{Mn}(\mathrm{II})$ and $\mathrm{Mn}(\mathrm{VII})$. The samples were: tap water, river water and mineral water. The river water samples were collected from Uberabinha River, which runs through an urban zone in the city of Uberlândia, and mineral water samples were acquired from a local store in the city of Uberlândia. Since the analyte concentration was below the detection limit, samples were spiked with the same concentrations of $\mathrm{Mn}(\mathrm{II})$ and $\mathrm{Mn}(\mathrm{VII})$ (4 and $50 \mathrm{mg} \mathrm{L}^{-1}$ ). Also, samples of a drinking water certified reference material (APS 1075) was used in the accuracy tests.

\section{RESULTS AND DISCUSSION}

\section{Optimization for the Selective Adsorption of Manganese}

Metals in aqueous systems are dissolved in different forms, some are present as simple hydrated ions, or ion complexes bound to organic ligands such as amines, humic and fulvic acids and proteins. Thus, the adsorption of the metals can occur through ion exchange mechanisms and complexation, which can even occur simultaneously [15]. In this context, the $\mathrm{pH}$ is a critical variable since it directly affects the manganese adsorption.

Since the seeds can adsorb cation and anions depending on the electrical charge on the surface, the initial $\mathrm{pH}$ of the solution is the determining factor in the separation of inorganic manganese species. Thus, controlling the initial $\mathrm{pH}$ of the solution may be sufficient to ensure a significantly different percentage of the adsorption of the $\mathrm{Mn}(\mathrm{II})$ or $\mathrm{Mn}(\mathrm{VII})$ species, thus promoting their selective extraction. The influence of the $\mathrm{pH}$ on the adsorption of the $\mathrm{Mn}(\mathrm{II})$ and $\mathrm{Mn}(\mathrm{VII})$ species is shown in Figure 1. 


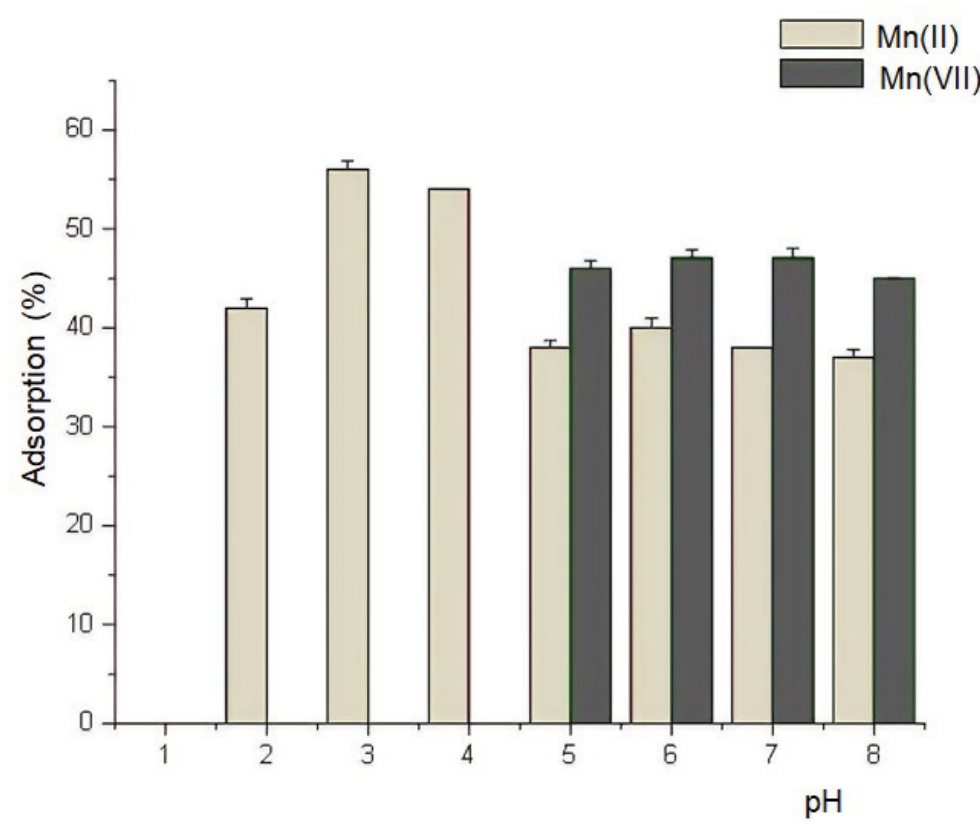

Figure 1. Evaluation of $\mathrm{Mn}$ species retention at different $\mathrm{pH}$ values.

Experimental conditions: Adsorbent mass $=0.5 \mathrm{~g}$, stirring time $=40 \mathrm{~min}$.

The isoelectric point determined for Moringa oleifera seeds is between 5-6 and for $\mathrm{pH}$ values under 6.0 the surface of moringa seeds has a positive charge [10]. In Figure 1 it can be observed that at $\mathrm{pH}$ values under 4.0, only the $\mathrm{Mn}(\mathrm{II})$ species is adsorbed, the highest adsorption occurring at $\mathrm{pH}$ 3.0. Thus, at $\mathrm{pH} 3.0$ it is assumed that the material is positively charged and can thus adsorb negative species, but, in acidic medium, $\mathrm{Mn}$ is predominantly in the $\mathrm{Mn}^{2+}$ form. The better adsorption observed can be attributed to the fact that the mechanism responsible for the metal retention by lignocellulosic adsorbents is based not only on ion exchange mechanisms but also complexation. So, at pH 3.0, the $\mathrm{Mn}(\mathrm{VII})$ species is predominantly in the uncharged form $\left(\mathrm{MnO}_{4} \mathrm{H}\right)$ and cannot electrostatically interacts with the adsorbent.

Another process that may be involved is the oxidation reactions of organic matter present in the seeds, promoted by the permanganate ion in alkaline medium $(\mathrm{pH}>6)$. Permanganate ion is a strong oxidizing agent. So, can be a conversion of $\mathrm{MnO}_{4}^{-}$to the insoluble $\mathrm{MnO}_{2}$, which cannot be quantified by F AAS in the supernatants [16]. Therefore, at pH 3.0, Mn(II) can be adsorbed with no adsorption of $\mathrm{Mn}(\mathrm{VII})$, allowing the selective separation of $\mathrm{Mn}(\mathrm{II})$ and $\mathrm{Mn}(\mathrm{VII})$ with $\mathrm{pH}$ control.

\section{Optimization Strategy for Mn(II) Adsorption}

Several variables can interfere with the adsorption process and in the next part of this study the variables evaluated were particle size, adsorbent mass and contact time.

The influence of varying the particle size of the Moringa oleifera seeds ( $\leq 500, \leq 300$ and $\leq 180 \mu \mathrm{m}$ ) on the $\mathrm{Mn}(\mathrm{II})$ adsorption was evaluated and the results are shown in Figure 2(a).

A decrease in the particle size had a favorable effect on the metal sorption, possibly due to the increased contact surface, suggesting an increase in the number of reactive sites, thus favoring ion adsorption by the adsorbent [17]. The experimental conditions for the study were: $\mathrm{pH} 3.0$, adsorbent mass $0.5 \mathrm{~g}$, contact time $40 \mathrm{~min}$ and $\mathrm{Mn}$ (II) solution concentration $4 \mathrm{mg} \mathrm{L}^{-1}$.

The influence of the adsorbent mass on the $\mathrm{Mn}(\mathrm{II})$ adsorption was studied by varying the mass $(0.05$, $0.5,1.0,1.5,2.0$ and $4.0 \mathrm{~g}$ ) of adsorbent. The percentage of manganese ions adsorbed increased with increasing mass up to $1.0 \mathrm{~g}$ of seeds, and then remained relatively constant (Figure 2(b)). This probably occurred because the system reaches saturation. Thus, a mass of $1.0 \mathrm{~g}$ is sufficient to ensure the 
adsorption of $\mathrm{Mn}(\mathrm{II})$ ions.

The effect of the contact time on the adsorption of $\mathrm{Mn}(\mathrm{II})$ was studied in the range of 5 to $120 \mathrm{~min}$ (Figure 2(c)). The amount of $\mathrm{Mn}$ (II) retained by the adsorbent decreased as the contact time was increased to $60 \mathrm{~min}$ and after this time there was no significant variation in the percentage of metal adsorbed, possibly due to the system reaching equilibrium. Since 15 min was sufficient time to ensure good adsorption, this time was selected for the subsequent studies, in order to obtain a simple and fast methodology.

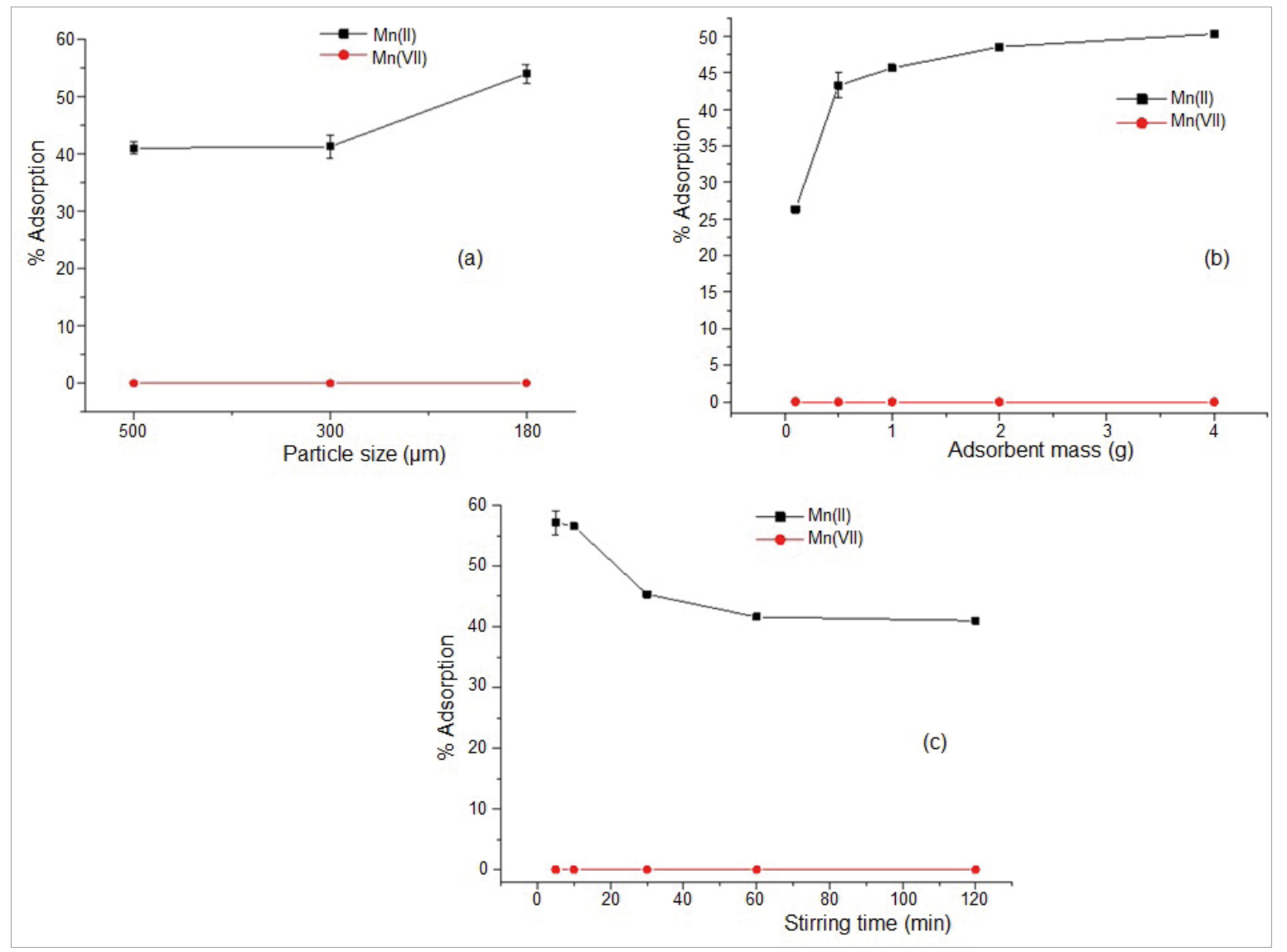

Figure 2. Percentage adsorption of $\mathrm{Mn}(\mathrm{II})$ onto Moringa oleifera seeds on varying the particle size (a), adsorbent mass (b) and contact time (c).

\section{Adsorption Isotherm}

The mechanisms associated with metal adsorption by biomass are still not clear; however, it is important to note that this process is not based on a single mechanism. Metal sequestration occurs through complex mechanisms, including ion-exchange and complexation, and it is quite possible that at least some of these mechanisms act simultaneously in various degrees depending on the biomass, the metal ion and the solution environment. The isotherm models can be used to describe this process.

Figure 3 shows the sorption isotherm for $\mathrm{Mn}(\mathrm{II})$ adsorption onto Moringa oleifera seeds. 


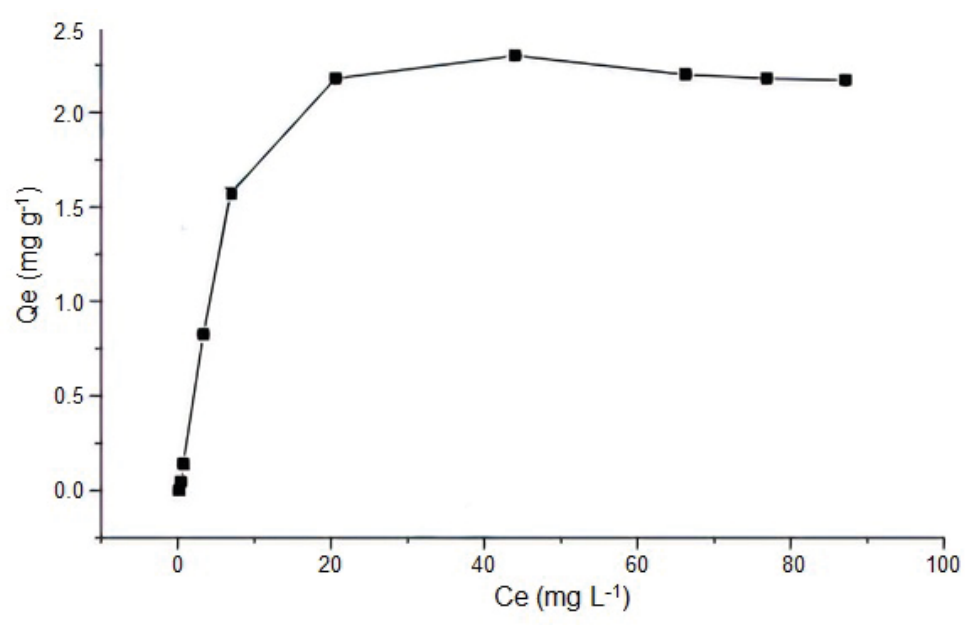

Figure 3. Adsorption isotherm for $\mathrm{Mn}(\mathrm{II})$ adsorbed onto Moringa oleifera seeds. Experimental conditions: $\mathrm{pH}=3.0$, adsorbent mass $=0.5 \mathrm{~g}$, stirring time $=15 \mathrm{~min}$.

Figure 3 demonstrates graphically the isotherm obtained, which can be compared with the class L proposed by Oscik [18]. The isotherms of this class are nonlinear and the slope is concave in relation to the abscissa. Since the sites on the adsorbent are all occupied, further adsorption of the adsorbate molecules is hindered. This behavior is expected in chemical adsorption and occurs for ion exchange or complexation [19].

The experimental data was analyzed using the Langmuir and Freundlich models, and the associated linearized equations are:

$$
\text { Langmuir equation: } 1 / q=1 / Q_{\max } \operatorname{Ce} b+1 / Q_{\max }
$$

Freundlich equation: $\log Q e=\log \left(K_{f}\right)+1 / n \log C e$

where: $\mathrm{Qe}$ is the amount of species adsorbed in the solid phase at equilibrium, Ce is the species concentration in the liquid phase at equilibrium, $Q_{\max }$ is the Langmuir parameter related to the maximum adsorption capacity, $\mathrm{b}$ is the constant related to adsorbent/analyte interaction forces, $\mathrm{K}_{\mathrm{f}}$ is the Freundlich constant and is indicative of the degree of adsorption and the constant $n$ is indicative of the heterogeneity of the surface of the solution.

The relative values of $Q_{\max }, K_{f}$ and $n$ calculated from the Langmuir and Freundlich models for the $\mathrm{Mn}(\mathrm{II})$ in the adsorbent are listed in Table I.

Table I. Parameters of the adsorption isotherm models

\begin{tabular}{ccc|ccc}
\hline \multicolumn{3}{c|}{ Langmuir } & \multicolumn{3}{c}{ Freundlich } \\
\hline $\mathrm{Q}_{\max }\left(\mathrm{mg} \mathrm{g}^{-1}\right)$ & $\mathrm{R}_{\mathrm{L}}$ & $\mathrm{R}^{2}$ & $\mathrm{~K}_{\mathrm{f}}\left(\mathrm{mg} \mathrm{g}^{-1}\right)$ & $\mathrm{n}$ & $\mathrm{R}^{2}$ \\
\hline 10.35 & 0.24 & 0.9943 & 1.19 & 9.3 & 0.9651 \\
\hline
\end{tabular}

As shown in Figure 4, when the Langmuir model was used to described the $\mathrm{Mn}(\mathrm{II})$ adsorption onto the adsorbent, the linear plot of $\mathrm{Ce}$ vs $\mathrm{Ce} / \mathrm{Qe}$, with a coefficient of determination of $\mathrm{R}^{2}=0.9943$, was obtained. When the Freundlich model was used, for the linear plot of $\log q v s \log C_{e}$ the coefficient of determination was $\mathrm{R}^{2}=0.9651$. 


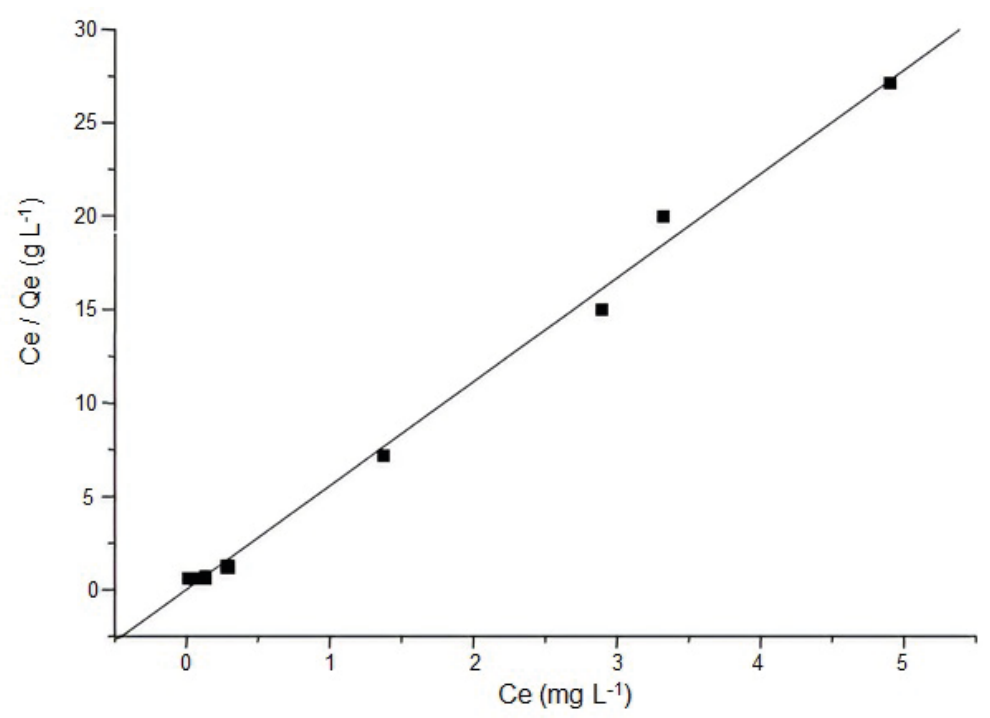

Figure 4. Plots of the Langmuir isotherm for the sorption of $\mathrm{Mn}$ (II) onto Moringa oleifera seeds. Experimental conditions: $\mathrm{pH}=3.0$, adsorbent mass $=0.5 \mathrm{~g}$, stirring time $=15 \mathrm{~min}$.

The results showed that the value for the coefficient of determination $\left(R^{2}\right)$ of the Langmuir isotherm model was higher than that of the Freundlich model. Thus, the experimental data are well fitted to the linear Langmuir isotherm, agreeing with the finding when compared to the system proposed by Oscik [18]. In the Langmuir model it is assumed that the adsorption is limited to the monolayer and thus maximum adsorption indicates the saturation of this monolayer. The process probably occurs through chemical adsorption, basically by ion exchange and complexation, and the maximum adsorption capacity of the adsorbent for $\mathrm{Mn}(\mathrm{II})$ was calculated to be $10.35 \mathrm{mg} \mathrm{g}^{-1}$. The $\mathrm{R}_{\mathrm{L}}$ factor was calculated and its value indicates favorable adsorption $(R L>1)$.

The good adsorption capacity of Moringa oleifera seeds for manganese is shown in Table II, where higher $Q_{\max }$ values can be observed when compared to results reported for the other natural adsorbents.

Table II. Comparison of methods for the manganese ion removal

\begin{tabular}{lcc}
\hline Adsorbent & $\begin{array}{c}\text { Maximum Capacity } \\
\left(\mathbf{m g ~ g}^{-1}\right)\end{array}$ & Reference \\
\hline Chitin + associated protein & 5.44 & {$[17]$} \\
Black carrot (Daucus carota) & 3.87 & {$[20]$} \\
Activated carbon (AC) derived from coconut shell & 2.54 & {$[21]$} \\
Tannic acid immobilized on AC & 1.13 & {$[22]$} \\
Moring oleifera seeds & 10.35 & This study \\
\hline
\end{tabular}

\section{Kinetic Studies}

Based on an analysis of Figure 2(b), it can be observed that manganese adsorption increases with increased contact time, reaching equilibrium.

The main models used to evaluate the kinetic profile were the pseudo-first-order, pseudo-secondorder, and intraparticle diffusion kinetic models. For the fitting of these models, two criteria must be satisfied. The first is that the linearity must be acceptably high $\left(R^{2}\right)$. The second is that the calculated $q_{e}$ 
values must be close to the experimental $\mathrm{q}_{\mathrm{e}}$ values.

Table III. Kinetic parameters for Mn(II) adsorption onto moringa seeds

\begin{tabular}{ccc}
\hline & Pseudo-first-order model & \\
\hline $\mathrm{K}_{1}\left(\mathrm{~min}^{-1}\right)$ & $\mathrm{q}_{\mathrm{e}}$ exp. $\left(\mathrm{mg} \mathrm{g}^{-1}\right)$ & $\mathrm{R}^{2}$ \\
\hline 0.2218 & 1.075 & 0.637 \\
\hline $\mathrm{K}_{2}\left(\mathrm{~g} \mathrm{mg}^{-1} \mathrm{~m}^{-1}\right)$ & Pseudo-second-order model & $\mathrm{R}^{2}$ \\
\hline 0.27 & $\mathrm{q}_{\mathrm{e}}$ exp. $\left(\mathrm{mg} \mathrm{g}^{-1}\right)$ & 0.999 \\
\hline $\mathrm{C}$ & 4.05 & $\mathrm{R}^{2}$ \\
\hline 2.58 & Intraparticle diffusion model & 0.994 \\
\hline
\end{tabular}

The kinetic parameters for the adsorption of $\mathrm{Mn}(\mathrm{II})$ ions onto the Moringa oleifera seeds (Table III) were obtained by linear regression of the graphic models of pseudo-first-order, pseudo-second-order and intraparticle diffusion. The calculated $\mathrm{q}_{\mathrm{e}}$ was 0.42 and the $q$ values determined experimentally are included in the table for comparison.

It can be noted that the kinetics of the manganese ion adsorption onto the seeds could be fitted with a pseudo-second-order kinetic model because it fulfills the two criteria mentioned above.

The $\mathrm{C}$ value (2.58) being different from zero indicates that the plot of qt vs $t^{0.5}$ does not pass through the origin and therefore the intraparticle diffusion mechanism is not the rate determining step of the transfer process, and other bulk mechanisms must act simultaneously in the control of the adsorption process.

\section{Accuracy Tests}

The accuracy of the proposed method was evaluated by recovery tests applying the method of standard addition using water samples (tap water, mineral water and river water).

By placing the samples in contact with moringa seeds under shaking, $\mathrm{Mn}(\mathrm{II})$ ions will be selectively retained and $\mathrm{Mn}(\mathrm{VII})$ will be free in the supernatant allowing its determination by $\mathrm{F}$ AAS. The Mn total concentration can be determined by direct analysis of the samples with the adsorbent without agitation, and thus the $\mathrm{Mn}$ (II) concentration can be calculated as the difference between the total Mn concentration and $\mathrm{Mn}(\mathrm{VII})$.

Since the concentration of analyte was below the detection limit, samples were spiked with $\mathrm{Mn}(\mathrm{II})$ in concentrations of 4 and $50 \mathrm{mg} \mathrm{L}^{-1}$ and the results for the recovery, shown in Table IV, are within the acceptable range of 80 to $120 \%$. 
Table IV. Determination of $\mathrm{Mn}(\mathrm{II})$ in water samples and experimental recovery in water samples spiked with 4.0 and $50.0 \mathrm{mg} \mathrm{L}^{-1} \mathrm{Mn}(\mathrm{II})$

\begin{tabular}{llll}
\hline Samples & $\begin{array}{c}\text { Mn(II) spiked } \\
\left(\mathbf{m g ~ L}^{-1}\right)\end{array}$ & $\begin{array}{c}\text { Mn(II) found } \\
\left(\mathbf{m g ~ L}^{-1}\right)\end{array}$ & $\begin{array}{c}\text { Recovery } \\
\text { (\%) }\end{array}$ \\
\hline Mineral Water & -- & N.D. & -- \\
& 4.0 & $3.6 \pm 0.2$ & 90 \\
\hline Tap water & 50.0 & $52.1 \pm 0.5$ & 104 \\
\hline River water & -- & N.D. & -- \\
& 4.0 & $3.7 \pm 0.1$ & 92 \\
& 50.0 & $48.1 \pm 0.3$ & 96 \\
\hline-- & N.D. & -- \\
& 4.0 & $3.9 \pm 0.2$ & 98 \\
\hline
\end{tabular}

N.D.: not detectable. $\mathrm{N}=3$.

The accuracy of the method was further evaluated by analysis of the drinking water certified reference material APS 1075. Table $V$ shows the results obtained. These results are consistent with the reference value, confirming the reliability of the method.

Table V. Determination of manganese in drinking water certified reference material

\begin{tabular}{lcc}
\hline Sample & Proposed method & Certified Value \\
\hline APS 1075 & $98.3 \pm 1.0 \mathrm{mg} \mathrm{L}^{-1}$ & $99.4 \pm 0.3 \mathrm{mg} \mathrm{L}^{-1}$ \\
\hline
\end{tabular}

\section{CONCLUSIONS}

The central point of the method developed in this study is the variation in the percentage adsorption of the inorganic species of $\mathrm{Mn}$ according to the $\mathrm{pH}$, since the $\mathrm{pH}$ changes the surface charge of the adsorbent, influencing its ability to adsorb cations and anions. It was observed that at $\mathrm{pH} 3.0$ only $\mathrm{Mn}$ (II) is retained, confirming the possibility of an extraction method with high selectivity.

The good accuracy of the method was observed through recovery tests and analysis of reference material. It was verified that the method can be applied in the selective extraction of Mn(II) from water samples using Moringa oleifera seeds as a bioadsorbent.

Manuscript submitted: March 25, 2019; revised manuscript submitted: June 24, 2019; revised for the $2^{\text {nd }}$ time submitted: August 16, 2019; manuscript accepted: August 27, 2019; published online: September 27, 2019.

\section{REFERENCES}

1. Clarke, C.; Upson, S. Neutoxicology, 2017, 58, pp 173-179.

2. Brown, S.; Taylor, N. L. Environ. Toxicol. Pharmacol, 1999, 7, pp 49-57.

3. Michalke, B. J. Chromatogr. A, 2004, 1050, pp 69-76.

4. Ozdemir, S.; Kilinc, E.; Poli, A.; Nicolaus, B.; Guven, K. Chem. Eng. J, 2009, 152, pp 195-206. 
5. Crossgrove, J. S.; Allen, D. D.; Bukaveckas, B. L.; Rhineheimer, S. S.; Yokel, R. A. NeuroToxicology, 2003, 24, pp 3-13.

6. Kazi, T. G.; Afridi, H. I.; Nazi, N.; Jamali, M. K.; Arain, M. B.; Jalbani, N.; Kandhro, G. A. Biol.Trace Elem. Res, 2008, 122, pp 1-18.

7. Gerber, G. B.; Léonard, A.; Hantson, P. Crit. Rev. Oncol. Hematol., 2002, 42, pp 25-34.

8. Tobiasz, A.; Soltys, M.; Kurys, E.; Domagala, K.; Dudek-Adamska, D.; Walas, S. Spectrochim Acta $B, 2017,143$, pp 11-16.

9. Silva, C. A.; Silva, R. L. S.; Figueiredo, A. T.; Alves, V. N. J. Braz. Chem. Soc., 2019. In Press.

10. Alves, V. N.; Mosquetta, R.; Coelho, N. M. M.; Bianchin, J. N.; Roux, K. C. P.; Martendal, E.; Carasek, E. Talanta, 2010, 80, pp 1133-1138.

11. Martins, I.; Martins, I. V. Cadernos de Referência Ambiental, 2001, 57, pp 1-121.

12. Barka, N.; Abdennouri, M.; Boussaoud, A.; Makhfouk, M. Desalination, 2010, 258, pp 66-71.

13. Bhatti, H. N.; Mumtaz, B.; Hanif, M. A.; Nadeem, R. Process Biochem, 2007, 42, pp 547-553.

14. Marques, T. L.; Alves, V. N.; Coelho, L. M.; Coelho, N. M. M. Bioresource, 2013, 8, pp 2738-2751.

15. Tarley, C. R. T.; Andrade, F. N.; Santana, H.; Zaia, D. A. M.; Biejo, L. A.; Segatelli, M. G. React Func Polym, 2012, 72, pp 83-91.

16. Burriel, F.; Lucena, F.; Arribas, S.; Hernández, J. Química Analítica Cualitativa, 1985.

17. Robinson-Lora, M. A.; Brennan, R. A. Chem. Eng. J, 2010, 162, pp 565-572.

18. Ościk, J. Adsorption. John Wiley \& Sons, Toronto, 1982.

19. Ndabigengesere, A.; Narasiah, K. S.; Talbot, B. G. Water Res.,1995, 29, pp 703-710.

20. Guzel, F.; Yakut H.; Topal G. J. Hazard. Mat., 2008, 153, pp 1275-1287.

21. Jusoh, A.; Cheng, W. M.; Low, N. A.; Megat, M. J.; Noor, M. Desealination, 2005, 182, pp 347-353.

22. Üçer, A.; Uyanik, A.; Aygün, S. F. Sep. Purif. Technol., 2006. 47, pp 113-118. 